\title{
Religious Harmony, An Important Factor in the Political Unity of Albanians in Years 1912-1924
}

\author{
Rudina MITA \\ Prof. Ass. Dr. , Faculty of Humanities, University of " Alexandër Xhuvani " Elbasan, Albania
}

\begin{abstract}
In the years 1912-1924, Albania was the place in which were four religions: Islam, Orthodox, Catholic and Bectashi. The ideological, political, cultural, educational movement known as the Albanian National Renaissance, (' 30 years of the XIX century until 1912 with the declaration of independence of Albania), it devoted an important attention of the political unity of Albanians face as chauvinistic platforms like Megaliideja and Narcetania. present at the time and at high risk for Albanians. The objective of these platforms was as much territorial and assimilationist. The equality of nationality and religion was an idea which was becoming bigger; who was turk was a Muslim, who was catholic was Latino, who was greek was Orthodox. Endangered the existence of a nation. Albanian Renaissance before 1912 aimed to find ways and approsiate means that political unity of Albanians does not sullied in front of assimilating platforms. An important political act for albanians was the Declaration of Independence from the Ottoman Empire on 28 XI.1912. In such a decisive moment religious unity should be an important part for the benefit of political unity. The motto of the Renaissance was "The religion of Albanians is Albanianism", which resulted successfully. During these years albanians demonstrate unity and religious tolerance for political unification. Among the facts that demonstrated this thing mentioned: The government proposed by Ismail Qemal (primeminister) in the moments of the declaration of independence was not approved by the Albanian personalities in the assembly of Vlora. As part of its dominant elements of the Muslim faith, being rewritten after the elements of the four religions in Albania. Proof of this religious unity was the Regency, (Supreme Council), in 1920 the functions of Monarch with four personalities of four religious which functioned until 1924. This clearly demonstrates that the Albanians of all religious in front of national interests were unique. Respecting religious affiliations between them.
\end{abstract}

Keywords: religious beliefs, unity, politics, albanians, platforms, assimilation

\section{Introduction}

As it is known in the course of history, ongoing invasions of the Illyrian's descendants dictated, arbers and later to the Albanians, their religions, until the historical reality that we object to this statement, the years $1912-1924$, Albania was the place of four religious: Muslim, Orthodox, Catholic and Bektashi. Despite this fact the report between religious and national feelings, has been in favor of national feelings. The national idea in Albania prevails over everything, even over religion. ${ }^{1}$ Since the beginning of XIX-th century (1809-1810 years), the political and literary english personality Hobhauz Xhon Kam, during a trip to the Balkan countries,concluded that albanias had a very strong national feeling, the love for their country. "When the people of the other countries in Balkan asked who they are, - write Hobhouz, - they say ,- we are mohammedan , or we are catholic, and the residents of this country (Albania) reply I am Albanian. " ${ }^{2}$ Always common for the albania territory and the albanians remaind the language no the religion, remaind the idea that they had albanian blood,despite of the religion.

\footnotetext{
1 Gabriel Hanotaux, writer of the prefece of the book of Gabriel Louis-Yaray, "Unknown Albanian, In the new Kingdom of Albania", Dituria 2006, pg.12-13.

${ }^{2}$ Academy of Science of Albania, "Albania Encyclopedic Dictionary", vol.Il, Tiranë 2008, pg 949.
} 
The major fact of our history is a very positive feature of our national development. With prominent traditional religious tolerance among Albanians, it also constitutes one of his more precious spiritual treasures, originality with which he enters aproud in family of civilized nations. ${ }^{1}$

Nation and religion were and are sacred for Albanians... A good religiosity was a good patriot,too. For Albanians the nation is and was before religion. God gives Nationality, while the religion is an each own choice. An albanian of whatever religion, was a man who fought with spirit for national dignity, liberty and who fought that his country not to be hurt. The Pashko Vasa's idea , "religion of Albanians is Albanianhood"2, was not a coincidence. "It is the generalization of a historical reality that continues to survive to this day." ${ }^{3}$ This characteristic feature for albanians is manifested from them in all stages of their historical development. Despite the Albanian religion, albanianhood has united them throughout the course of history, has provided their political unity in all efforts for freedom and independence. Albanians although located among several religions, arose on them and remaind a single nation and undivided. We are dealing with an undisputable historical merit of our people, which rose above religious divisions, do not let them turn into political and religious divisions, as it has happened in other nations.... Today the obligation of Albania is to preserve this historic victory of their ancestors. ${ }^{4}$ It appeared even rose to new levels especially during the period of the Albanian Renaissance, (it launched in the 30-40 th century. XIX until 1912 with the Proclamation of Independence) when national and religious unity of Albanians,so their unity and political union in national movement successfully withstood anti chauvinistic attempts of political platforms, Megal-idea and Narcetania, etc. that aimed at the occupation of Albanian lands. It was propaganded too much, the reconciliation of nationality and religion: who was Muslim considered Turk, who was Catholic was considered latin, who was Orthodox was considered greek. Endangered the existence of a nation. Renaissance's man of Albania found the best ways that the political unity of Albania wasn't violated. This was expressed by the creation of the Albanian League of Prizren on June 10, 1878 which realized the unification of Albanians regardless of religion and submit their applications with political and national character. Mucise Unlu, an ottoman researcher, noted that: "between Muslim, Catholic and Orthodox Albanians ,(partecipants in LSHP-RM), there is no discussion, it is not religion that unites them, but before anything, they are Albanians. " 5 "so Albanianhood, national feeling". ${ }^{6}$ Renaissance motive was albanianism and nationalism. Expressions: "Keep our love for the nation and freedom hightest, that without freedom and nationality there is no homeland, and without homeland there is no religion. "Les Balkans", an Athine magazine of years 30, sympathetic of Albanian independent, wrote that the history of Albanians wars for independence, proves that: "When they (Albanians-R.M.) had to battle for freedom, religious issues have passed into the background ". The author welcomes... tolerant spirit of the Albanians, who loves his country indefinitely, when it comes to independence minimizes religious difference... Patriotism, nationality, is one of the most distinctive characteristics of their character at all times." ${ }^{7}$ The national historic events of 1912 that preceded the independence of Albania: the general uprising,the Assamble of Junik (May 1912), the assamble of Sinja and the memorandum of July 23, 1912 in whose the albanians participated despite of religion, showed the unity of albanians regardless of religion and region, to include Albania in the way of civilizacion. "We, - said in one of the request that the insurgents addressed to the europian states,- we go to war and death to this sacred ideal, regardless the religion: a hight religion, who passed all, makes us brothers, inspires us, moves us, leads us, the resurrection of our homeland, unity and freedom ..." ${ }^{\prime 8}$ The Albanian National Renaissance Movement was finalized with the collection of the National Assembly of Vlora and the Albanian declaration of independence on November 28, 1912. The assembly of Vlora united all the albanians of every religion. Interfaith Cooperation for the national cause is clearly evidenced in the act of "Declaration of Independence regardless of religion, National Assembly composed of delegates of all Albanian territories, regardless of religion, gathered today in Vlora proclaimed the independence of Albania"g... Not only the representation in Parlament but also the government created by him that had an incluseve national and religious character was an expression of political unity of all

\footnotetext{
${ }_{1}^{1}$ Gazmend Shpuza, "Albanianhood above all", Alenanca's Newspaper, date 22 september 1995, pg. 13.

2 Beqir Haqi, Religion and Nationality, "Man", nr.11 (23), june, Tirane, 1944, pg. 2.)

${ }^{3}$ Gazmend Shpuza, "Albanianhood above all", Alenanca's Newspaper, date 22 september 1995, pg. 13

${ }^{4}$ Gazmend Shpuza, "Albanianhood above all", Alenanca's Newspaper, date 22 september 1995, pg. 13

${ }^{5}$ Kujtim Nuro, Hight gate don't known Kosovo!, Albanian Newspaper, 13 dicember 2015.

${ }^{6}$ Gabriel Louis-Yaray, "Unknown Albanian; In new kingdom of albanians”, Dituria 2006, pg.149..

7 Taken from Lord Broughton, 1851,

${ }^{8}$ Isuf Bajrami "The declaration of independence can not be realized without national unity and territorial unity ", Monday, 03 Dicember 2012 09:15 (http://2lonline.com/arkiva/opinion/8725-shpallja-e-pavaresise-nuk-mund-te-realizohej-pa-bashkim-kombetar-e-unitetterritorial.html)

9 Institute of History, "Lef Nosi-Historic Documents 1912-1918", Tirane 2007, pg.107
} 
Albanians... The Primeminister was elected Ismail Qemali. And in the first government of the Albanian state were represented all religious communities harmonized based on national interest. By creating it and by creating their own state, Albanians assured the leading center .. "it will unite under the banner of Albania, the Albanian people" "The principle of building state institutions on the basis of representation of all relions was implemented as the composition of Senate as well as in government (1912-1914.... Principles with entire national character and entire religious character... They will serve as a guide in the relations of the new state with religious institutions..." 2 Vehbi Dibra chairman of the Senate that created the National Assembly of Vlora was Muslim but in the declaration of Independence declared that .. "Christian and Muslims are inseparable Albanian brothers" 3 Vlora government failed to extend its authority and power throughout Albania, after the most of the Albanian territory was found occupied by the armies of neighboring states. In occupied territories the invaders was trying to sow the seeds of hatred and division to destroy the harmony between Albanians of different faiths in function of their policies,but without results. In connection with this quote: At the beginning of December 1912 the Serb commander in Elbasan, colonel Hadzic, gathered castle Orthodox men in the Metropolis church and told...: "Listen men, Turk finished once and forever for the crimes, robberies, rapes that are committed by Turks on the Christian element, so against you..." At the end one of the present man said: "Christians in Elbasan have not had war or persecution by Muslims, but elements of Muslim and Christians religious together have declared the independence of Albania, distracting from the Turkish occupation."4 Vlora government remained in power from December 1912 until January 1914. Decisions of the Conference of Ambassadors in London not only halved the Albanian territory, but they decided at the top of Albania the German Prince V. Vidin and the protectorate of six Major Powers on the remaining territory. Prince Vidi cames in Albania on March 7, 1914. The choice of Prince Wilhelm of the Protestant faith by the Great Powers, in a place like Albania with four religion, was not without purpose, becouse the arrival of the prince intended political stability and tranquility in the country, away from any religious influence and regional impact. The composition of the government was being on the basis of representatives of all religious faiths. Organic Status of Albania established the ICC adopted on April 10, 1914 designated as the Principality legislature the National Assembly with 36 members, where 21 were directly elected and 10 members were elected from the Prince. "Because of the duty 4 members were representatives of religious communities, and the Albanian High Commissioner at the National Bank." ${ }^{\prime 5}$ After the outbreak of World War I. Prince Vidi after a 6-month that he stayed at the top of the Albanian state, in September 3, 1914 left Albania. The place was engulfed by an anti-rebel insurgency of the Center Albania, promoted and organized by antialbanian foreign districs, directed by some Turkoman and esadist elements aimed at restoring under the Ottoman regime.

Against these elements arose Albanian religious patriots like Vehbi Dibra ${ }^{6}$, who in those difficult moments stressed addressing all Albanians : ... "Our People small in number, that were enough contracted and bloody in wars with foreigners, had not neccisity to killed with each-other, neither the goverment, neither the people, neither the nation, had no interes that albanian bllod be shaid for close one's interests: but the country,needed peace, to unite all for a purpose, for the progress of the Nation."

Beginning and development of anti-national uprising of 1914-1915 years in central Albania, followed by the introduction and invasion of Albania by the armies of two warring blocs of the First World War 1914-1918, wich crumbled land in their occupation zones. In Albania there was no state institution survived. But even in those circumstances there were attempts of Albania religious patriots, and their requests sent to international institutions to defend the territorial integrity of the country. "At Anton Harapi draft memorandum of 1918, towards the Great Powers signed by Christian and Muslim, Archbishop Serreqi wrote to the League of the Nations: "We are here becouse Kosovo and Cameria .. we are all one blood daughter of a land." In december 1918 to precede decisions of the Conference of Peace in Paris, Albanian patriots tried by every means and at any cost to be represented at the conference. For this intention, convented the Durres' Congress in December 25, 1918, wich created the Government with Turahan Pasha Permetin Priminister. The Government of Durres had the politicans from all the lands and of all of religions in Albania. The government announced in its program attempts

\footnotetext{
${ }^{1}$ A.Puto, "The albanian's independence and the diplomacy of Great Powers 1912-1914", Tirane 1978, pg.126-127, "The freedom of Albania ", Sofje,22.07.1913.

2 Muin Çami "Albania throught the History", Onufri 2007, pg. 28-29

${ }^{3} \mathrm{http}: / / 2$ lonline.com/arkiva/opinion/8725-shpallja-e-pavaresise-nuk-mund-te-realizohej-pa-bashkim-kombetar-e-unitet-territorial.html

${ }^{4}$ Shyqyri Demiri, "Brief history of the region of Elbasan", Tiranë 2006, pg. 125

${ }^{5}$ Afrim Krasniqi "Political systems in Albania (1912-2008), Tirane 2009, pg. 37-39.

6 In 1913, The Provisional Goverment of Vlora task him the General Muftu of the Muslim Community throught Albania

7 https://sq-al.facebook.com/notes/peshkopi-diber-albania/haxhi-vehbi-dibra-1867-1937/342031142542562/
} 
to... "to have an Albania of albanians" in boundaries that God has Faur, and where the albanian lenguage is spoken, Albanian seeds, the oldest in the Balkans, had been able to preserve their nationality, the spirit of liberty and independence of its." ${ }^{1}$ Durres Government chose and sent an official delegation consisting of Turhan Pasha, Luigj Bumci, Luigj Gurakuqi, Mihal Turtulli, Mehmet Konica, Gjergj Fishta, Mehdi Frasheri which will attend in the Conference of Peace in Paris. Mihal Turtulli, member of albanian delegation in Conference of Peace in Paris, in session of Febbrary 27, 1919 said that: ... " Albaninans based their requirement in nationality and soul of population... It is known all around the world that in lands wich are called from greeks like the North Epir, while we called the south Albania there is no greek... they think that cristians , as $i$ am, are greeks, but this is incorrect..." ${ }^{2}$ All the Albanian delegation members ${ }^{3}$ of Durresi Government in Paris, even those were from different faith, in the same unity, signed the Memorandium in wich define the proposals presented to the Peace Conference regarding Albania, by opposing the decisions of Conference of Ambassadors in London. ${ }^{4}$ AntiAlbanians and annexation plans being discuseed in the table of the Peace Conference for new territorial fractures in Albania, caused the reaction of all Albanians and Albania National movement. To oppose antialbanian plans and for protect Albanian state convend from 21 to 31 Janary 1920 National Congress of Lushnja. This Congress, by academic Arben Puto, was a recovery of the national idea in a new dimension. ${ }^{5}$ Lushnja National Congress became clear expression of political unity, unity and readiness of Albanians based on national interests, beyond any religious division, to protect the nation. Regency, with the functions of head of state,an organ created by Congress, composed from four members of four religions in Albania. In choising of these personalities was not only attended religious or politic criterion, but also regional expansion. "... They was choisen for their patriotism, wisdom and experience, but also as representatives of four religions in the country: Mohammedan: Abdi Toptani, Orthodox, Sotir Peci; Bektashi: Akif Pasha Elbasani and Catholic, Bishop (Louis) Bumçi "6 " Never in its History,- said this day Akif Pasha Elbasani,- Albanian Nation wasn't united as it is today, with a desire to have their government, after the "Albania for Albanians" formula." 7 Representation in National Concil, Government and Hight Council (organs created by Lushnja Congress), the politicans of all the religions and politicians of the albanians lands, shows clearly that decisions and state organs created had a national character. During the 1920-th year, Albania attempted for membership in the League of Nations, where our state was presanted from Fan Noli, a vizionary politician, curchman by profession and orthodocs faith. It was no coincidence that in a country with four religions and with overwhelming majority Muslim population, to attend an Orthodox as representatives of Albania in National League. This was a dignifying expression of a country aspiring for membership, with national unitary spirit despite religious divisions. In Dicember 17 , 1920 Albania and albanians become part of National League. An iportant historical moment for albanians were the first parlamentary and pluralist ellection of April 1921. It was the first experience in the pluralist and parlamentary political life. Naturally that during the ellection will appear obstacles and difficulties. Foreign antialbanian circles tried to prevent the development of the electoral process in some regions of the country.Albania Government supported by all religious opopulation, reacted sharply to these attepts. The first parlamentary ellections in Albania lasted 2-3 month (febbrary,march,april 1921) and ended in April 5, 1921. This ellections attested the strong national politic volition of albanians electors. Even a small attempt to confuse and organized conflicts between Muslims and Catholics failed. British resercher R. Hibert noting the Albanian national feelings and the fondamental role of their albanicism, at that time emphasize that their political succses in this event prove "Albanianism - without changing religions. Patriotism victory in parliamentary elections marked another political success "on opponents of Albania State and on the opponents of its parlamentary democratic constitution, whose exaclly during the parlamentary elections played very strong the letter of provincial, religious and territorial division, threatened to challenge one of the new European countries, one of the oldest nation in Europe..." (Reginald Hibert) cito?

During the period 1920-1924 the members of cabinet government were politicans of differents religions. In May 21, 1923 National Concil put on the agenda the discussion for the draft law for the religious communities. The main discussions in

\footnotetext{
${ }^{1}$ Kastriot Dervishi, "The History of the Albania State 1912-2005", Tirane 2006, pg. 90.

2 The same, pg.92.

${ }^{3}$ Luigj Bumçi, Mihal Turtulli, Mehmet Konica, Mehdi Frashëri, Luigj Gurakuqi.

${ }^{4}$ Academy of Science Alb, Institute of Histori, General Directory of Archive, "The war of Albanians for national liberation 1918-1920, vol. I, Tirane 1975, pg. 498

${ }^{5}$ Newspaper "Shqip", June 18, 2012, Prof. Arben Puto "Albania , state of national unity and inseparable"

6 Tajar Zavalani "History of Albania", Phoeniks 1998, pg. 259

${ }^{7}$ M.Çami,"The war of Albanian people for national liberation (documentary), Tirane,1976, vol Il-të doc.89 (Isuf Bajrami "Declaration of Indipendence can not realize without national unity and territorial unity", Monday, Dicember 03, 2012 09:15)
} 
this session focused about the nationality of the directors of religious communities in Albania. Fauf Fico proposed that the directors "of all the religions in all the instants, should be albanian citizen, and at least two generations, ethnic Albanians, and at least two generations, with Albanian nationality." Fan Noli proposed that the clerics (directors) were Albanians and enjoy political rights"2 This discussion were done with the intention that realized the state unity, reconciliation and nationalizy of religion. According to the legal status of religious communities, stated among other things that: "Senior Clergy should be Albanian citizen, to know albaninan language, enjoy civil and politic rights, to be from Albanian race for at least three generations." Harmonization of the Albanian national consciousness with the religious consciousness was evidenced significantly during the 1920-1924 years. In consolidation of the Albanian state a very important role played the religious institutions. "on top of which came new elements... wich have battled for doing the curch and mosque , institution with national spirit.

If at the time of the Declaration of Independence Albanian state declared itself separate from religion, what it was essentially an act of quite advanced for the time, the religion institucions in Albania were not diveded from their leading religious centers abroad, which inspired not only religious dogma, but also dictate the policy. ${ }^{4}$ But the albanian personalities in charge of religious institutions attempted to disconnect from centers abroad Albania. In January 17, 1921 albanian bektashi organized the First Bektashian Congress, wich declared the Albanian Autocephalous Bektashi Clergy. ${ }^{5}$ In 1923 The First Congress of Albania Muslim, proclaimed the independence (autocephaly) of Albanian mosque. ${ }^{6}$ These were acts with national character, becouse representied subsidiary acts of indipendence and sovranity of Albania state. ${ }^{7}$

Even today religious harmony is one of the most notable virtues of the Albanian Nation. Its express in the good relations, in mutual respect between elements with different religions, even in recents years in Albania, these are strengthened not only in religious coexistence, but also in joint cooperation contributions, but also in cooperation for the establishment of building religious institutions. In Milot communes, of Malbardh village with 900 residents, are only 9 houses with residents of catholic faith, and the other residents are Muslum and all contributedand helped for the Catholic church building. Also the catholic people contributed for Mosque construction. The same happened in Derven village, no far Kruja city, where muslum people helped to contruct the church and then catholic people helped to construct the mosque. Regardless of religion muslum and catholic are united for building this religious institutions and this holy places. Based on the tolerance values, citizens celebrate Cristmas, Easters, Bajram, and the month of Ramadan etc. This religious harmony and the solidarity of human brotherhood is a special virtue for Albania and for all Albanians people, because all around the world only Albania has this attribute. This appreciated and noted Pope Rancesk "Albania,- said Pope,-- is a model no only of the co-ecxistence, but also brotherhood among different religions." 8

\footnotetext{
1 Kastriot Dervishi, "Albanian State History 1912-2005, Tirane 2006, pg.171.

2 The same, pg. 172

3 The same, pg.172.

${ }^{4}$ Muin Cami, "About the hamonizationof the national and religious conscience in Albania 1921-1924", The Magazine Human Rights. 3(23)-2000 pg 65.

5 Science Academy, A. R.., FESh. Vol. I pg. 203. In Berat Congres September 10-19, 1922 founded Albania Autocephalous Orthodocs Curch (KOASH--R.M.) pg. 1262.

${ }^{6}$ Science Academy A. R., FESH, Vol. 2, Tirane 2008, pg 1260

${ }^{7}$ Hasan Dosti, "Hasan Dosti for Fan Nolin. In book FLAMURTAR I KOMBIT. Study Seminar on the occasion of the Centennial of the Birth of Theofan S. Noli, pg 28. Published by PanAlbanian Federation of America Vatra 517 East Broadway Boston, MA.02127.
}

8 "Today" newspaper, dt. Janary 19,2016 